\title{
PENGEMBANGAN SENI PERTUNJUKAN LANGEN MANDRAWANARA SEBAGAI ASET PARIWISATA DI DESA SEMBUNGAN KABUPATEN BANTUL
}

\section{Kuswarsantyo}

\section{FBS Universitas Negeri Yogyakarta}

\section{Abstract}

Langen Mandrawanara is one of rare arts, created by Patih Danurejo in the reign of Sultan Hamengkubuwana VIII. Besides its low frequency of performance, the rareness is caused by the difficulties of that dance with Ramayana epic theme. The art of Langen Mandrawanara is performed with squatting and the dialogs are carried out through tembang, traditional Javanese songs. The difficulties make Langen Mandrawanara less interesting to young generation incapable of singing the songs.

As the time goes by, efforts are made by art groups and organizations to preserve Langen Mandrawanara, which are good steps to support the art preservation. The one carried out by Langen Mandrawanara community in Sembungan Village, Bangunjiwo, Bantul becomes the key to the future of the art. The endeavor also becomes an appeal to the tourists.

The application of pseudo traditional arts is quite relevant as an attempt to keep Langen Mandrawanara art improving, without neglecting its essential aspects to be preserved. Using a dynamic concept of performance, Langen Mandrawanara is hoped to attract the viewers, especially of the young generation.

Key words: Langen Mandrawanara, preservation, tourism

\section{A. Pendahuluan}

Daerah Istimewa Yogyakarta (DIY) memiliki kekayaan dan potensi seni pertunjukan yang tersebar di berbagai wilayah. Kekayaan tersebut dapat digunakan untuk mendukung program pemerintah dalam upaya pengembangan Daerah Tujuan Wisata (DTW). Namun kenyataan yang terjadi , kekayaan tersebut belum dapat dimanfaatkan secara maksimal oleh para pengelola bidang jasa wisata Masalah utama adalah bagaimana memanage pertunjukan tersebut dengan kemasan khusus, sehingga akan menarik wisatawan.

Masalah kedua kurang koordinasi diantara para pejabat bidang pariwisata dalam pemetakan wilayah dengan jenis pertunjukan yang dimiliki. Permasalahan ini merupakan salah satu penyebab mengapa Yogyakarta sebagai DTW masih rendah Length of Stay (lama tinggal) nya. Daerah Istimewa Yogyakarta saat ini masih terkesan Ramayana oriented dalam menghadirkan pertunjukan untuk wisatawan. Padahal jenis kesenian lain masih banyak, seperti Mahabarata, Panji, Menak. Kalaupun tetap mengacu pada epos Ramayana tentu dalam format yang 
berbeda dengan Ramayana yang sudah ada di Prambanan atau di Purawisata. Bentuk lain itu adalah Langen Mandrawanara (Opera Jawa dengan cerita Ramayana). Pertunjukan ini sangat unik, karena dibawakan dengan berjongkok dan dialognya dengan tembang.

Sembungan sebuah desa yang terletak di wilayah kecamatan Kasihan, Kabupaten Bantul, merupakan tempat tumbuh berkembangnya kesenian tradisional ini. Para pendukung pertunjukan sangat variatif, dari petani hingga mahasiswa membaur jadi satu. Letak desa Sembungan sangat dekat dengan sentra kerajinan kemarik Kasongan, sehingga apabila tempat ini dapat dijadikan tempat pertunjukan wisata akan sangat prospektif untuk program pariwisata. Oleh sebab itu tulisan ini akan fokus membahas bagaimana Pengembangan Seni Pertunjukan Langen Mandra Wanara di desa Sembungan sebagai Aset Pariwisata, Kabupaten Bantul.

\section{B. METODE PENELITIAN}

Penelitian ini menggunakan metode kualitatif dengan pendekatan multidisipliner guna memperoleh data-data yang dibutuhkan. Sumber data dalam penelitian ini adalah pertunjukan Langen Mandra Wanara yang hidup berkembang di desa Sembungan Bangunjiwo, Kasihan Bantul. Dari bentuk pertunjukan tersebut akan dikembangkan untuk konsumsi wisatawan, sehingga memunculkan bentuk sajian kemasan khas Langen Mandrawanaran desa Sembungan.

Pemerolehan data penelitian dilakukan dengan cara, (1) pengamatan intensif pertunjukan dan (2) wawancara dengan pencatatan. Kegiatan pengamatan intensi dilakukan untuk menemukan beberapa aspek yang dapat memberi daya tarik penyajian Langen Mandra Wanara. Selanjutnya dari hasil amatan tersebut dirumuskan ke dalam format atau bentuk penyajian yang sesuai dengan kemasana wisata.

Penelitian ini akan dilakukan dengan

1. Observasi dan survei ke lapangan dengan objek tempat pertunjukan wisata yang selama ini belum terekspose (terpublikasikan).

2. Mengadakan pendokumentasian jenis pertunjukan tersebut untuk dikemas menjadi pertunjukan wisata.

3. Ketiga melakukan analisis dan studi kelayakan tentang jenis pertunjukan serta prospek pengembangannya ke depan dengan menggunakan prinsip-prinsip pengembangan pariwisata.

Data-data akan kami kumpulkan melalui rekaman video untuk dijadikan bagian dari laporan penelitian ini. Selain itu dalam analisis data akan dibantu dengan menggunakan beberapa referensi yang relevan dengan kajian masalah seni wisata. Di samping wawancara dengan nara sumber yang telah kami sebutkan di atas.

Hasil yang diharapkan dari penelitian ini adalah, desa Sembungan akan menjadi daya tarik wisatawan untuk berkunjung ke desa tersebut, sehingga lama tinggal wisatawan ke Yogyakarta akan semakin tinggi. Dengan demikian income daerah dari sektor pariwisata dapat meningkat. Di samping itu dari program ini diharapkan kesejahteraan masyarakat sekitar desa Sembungan akan ikut terangkat karena kunjungan wisatawan mancanegara dan atau nusantara yang datang menyaksikan pertunjukan Langen Mandrawanara.

Analisis data dilakukan dengan teknik deskriptif kualitatif. Langkah analisis yang ditempuh yaitu identifikasi, klasifikasi, tabulasi, dan interpretasi. Kegiatan identifikasi dilakukan untuk menemukan aspek yang mampu memberi daya tarik dalam sebuah pertunjukan Langen Mandrawanara. Hasil identifikasi dikelompokkan sesuai dengan permasalahan penelitian dalam dua aspek yaitu: (a) Bentuk penyajian Langen Mandrawanara dan (b) cara pengembangan untuk konsumsi wisatawan Langkah berikutnya yaitu interpretasi data. Kegiatan interpretasi dilakukan dengan berdasarkan pada hasil pengamatan, wawancara dan catatan selama proses penelitian.

Dalam penelitian ini kesahihan yang digunakan adalah kesahihan yang berorientasi pada data hasil pengamatan, wawancara yang relevan dengan konteks penelitian. Untuk kehandalan dalam penelitian ini digunakan kehandalan berdasarkan kemunculan kembali (reproducibility). Kemunculan kembali menunjukkan seberapa jauh suatu proses dapat diciptakan kembali dalam berbagai lingkungan, pada tempat yang berbeda, menggunakan pengkodean yang berbeda. Teknik kemunculan kembali dalam penelitian ini dilakukan dengan pembacaan dan interpretasi berulang-ulang oleh peneliti. Dari pembacaan intensif dan berulang-ulang diharapkan dapat diperoleh hasil yang memenuhi kriteria kehandalan.

Subjek penelitian ini akan melibatkan komunitas seni tradisi Langen Mandra Wanara di desa Sembungan, Bangunjiwo, Kasihan Bantul. Nara sumber utama adalah pimpinan grup Langen Mandrawanara., yaitu Ki Jiwaraya. Selain itu juga akan menjaring pendapat tokoh masyarakat sekitar tentang prospek ke depan kesenian Langen Mandrawanara sebagai sajian wisata. Untuk pakar pariwisata yang dapat membantu untuk proses penelitian ini adalah Ir. H. Yuwono Sri Suwito, MM selaku praktisi Pariwisata yang telah berpengalaman.

Dalam sebuah bukunya yang berjudul The Hula, Jerry Hopkins mengungkap bahwa dengan sebuah pertunjukan Hula yang sangat sederhana, kepulauan Hawaii (negara Bagian USA) menjadi sangat terkenal di mata dunia. Akibatnya industri pariwisata di negara bagian USA ini menjadi pemasok hasil devisa negara terbesar. Sampai awal 1990-an Hawaii dibanjiri wisatawan mencapai 7.000.000 setahun (data Soedarsono, 1990)

Satu hal yang membuat daya tarik daerah tersebut adalah budaya tradisional orang-orang Polynesia yang menghuni kepulauan tersebut. Lebih 
lanjut dikemukakan bahwa kehidupan agama dan adat yang sangat unik, di mana Hula menjadi salah satu bagian dari seni budaya di daerah ini.

Nelson HH. Graburn dalam bukunya yang berjudul Etnic and Tourist arts (1976) membahas tentang seni wisata di negara berkembang. Dengan meminjam konsep J. Maquet, Graburn mengungkapkan bahwa produk seni berdasarkan jenis penikmatnya dibagi menjadi dua kategori :

1. Seni yang memang dibuat untuk dinikmati masyarakatnya (art by destination)

2. Seni yang dibuat memang untuk orang lain (pendatang/wisatawan) disebut dengan art by metamorphosis.

Seni wisata masuk dalam kategori kedua. Dengan demikian seni wisata harus mampu menyesuaiakan dengan selera penikmatnya. Dengan demikian seni kategori kedua ini disebut juga sabagai seni akulturasi. Selain itu karena cirri-ciri tradisional masih selalu hadir dalam seni kelompok kedua ini, tetap nilai-nilai sakral dan magisnya telah dihilangkan, maka seni akulturasi ini disebut dengan pseudo traditional arts.

Soedarsono dalam tulisannya berjudul Dampak Pariwisata terhadap perkembangan seni pertunjukan Indonesia (1986) selain memaparkan kehadiran seni wisata sebagai akibat hadirnya industri pariwisata, juga memberikan saran bagaimana cara kita menanggulangi pengalaman yang pernah menimpa Hawaii. Dengan meminjam diagram Theodore M. Greene dalam tulisannya yang berjudul The Scope of Aesthetics (1967), Soedarsono menyarankan agar domain seni jangan sampai ditelan domain industri pariwisata.

Gambaran lebih jelas dapat kita lihat pada diagram di bawah ini :

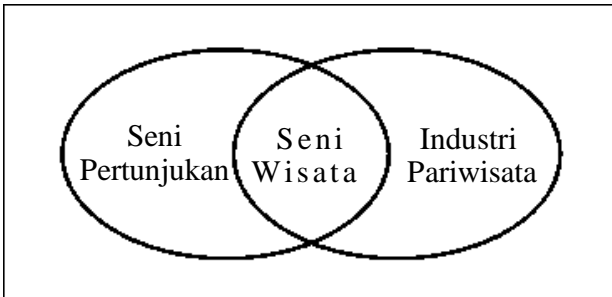

Melihat perbandingan antara dua domain tersebut maka optimalisas pengembangan seni pertunjukan di daerah hendaknya sadar betul untuk menerapkan konsep yang telah dikemukakan Soedarsono di atas. Dengan demikian pengembangan daerah tujuan wisata tidak akan merusak ekosistem seni perttunjukan itu sendiri sebagai seni tradisi warisan leluhur yang harus dilestarikan.

Kajian tentang tema seni pertunjukan kiranya telah banyak dilakukan beberapa peneliti terdahulu. Soedarsono (1995) melakukan penelitian dengan fokus perkembangan bentuk seni pertunjukan Jawa sebagai sajian wisata.
Penelitian ini sangat penting untuk informasi seni tari Jawa masa kini dalam menghadapi tantangan industri pariwisata. Meski dalam bagian lain penelitian ini mengungkapkan kekhawatiran tentang padatnya jadwal pementasan seni tari, yang akan mengakibatkan kemerosotan nilai artistik pada seni tari itu sendiri.

Dalam penelitian terdahulu, Kuswarsantyo (1996) melakukan penelitian tentang "Perkembangan Tari Jawa di Yogyakarta Dalam Menghadapi Tantangan Industri Pariwisata". Penelitian ini mencari sisi positif hadirnya bentuk-bentuk kemasan wisata. Konsep yang strategis dalam menghadirkan pertunjukan wisata adalah Pseudo Traditional Arts atau seni tradisional tiruan yang dikemukakan J. Maquet. Dalam penelitian ini peneliti telah berhasil membuktikan bahwa hadirnya pertunjukan kemasan wisata justru berdampak positif bagi eksistensi seni pertunjukan tradisional itu sendiri. Lebih lanjut hasil analisis data penelitian ini didukung dengan penggunaan diagram Wimsatt yang akan semakin meyakinkan posisi seni wisata terhadap keberadaan dan memperkaya khasanah seni pertunjukan.

Rasa optimis tentang masa depan perkembangan seni kemasan wisata juga dikemukakan Soedarsono (1990) dalam sebuah penelitian tentang Seni Pertunjukan Jawa Tradisional dan Pariwisata di Daerah Istimewa Yogyakarta Dalam penelitian ini dikatakan bahwa kesulitan memasarkan seni pertunjukan akibat lemahnya dukungan komersial (commercial support) dari masyarakat, pada akhirnya akan memperoleh kesempatan yang lebih baik setelah kehadiran wisatawan mancanegara ke Indonesia, karena akan melahirkan produk-produk seni pertunjukan yang dapat dikategorikan sebagai seni wisata.

Dalam kaitannya antara seni pertunjukan dengan masalah sosial, secara jelas telah diungkapkan Sedyawati (1981) bahwa, perkembangan sen pertunjukan sangat ditentukan oleh dua faktor, yaitu pertumbuhan masyarakat yang akan memberi pengaruh langsung pada corak seni. Dan kedua daya cipta seniman sebagai faktor yang paling menentukan bagi kelangsungan seni pertunjukan itu sendiri.

Menyinggung pembahasan tentang seni kemasan wisata Kayam (1981) menyatakan bahwa, seni pertunjukan adalah unsur penyangga kebudayaan. Oleh sebab itu upaya pelestarian dan pengembangannya harus tetap kita jadikan prioritas, dengan tanpa harus mengorbankan aspek pendukungnnya. Referensi lain yang digunakan adalah terkait dengan bisnis pariwisata dan seni pertunjukan. Spillane (1971) mengungkapkan bentuk-bentuk seni kemasan wisata harus diantisipasi dengan penanganan manajemen secara benar, sehingga tidak mengorbankan unsurunsur yang esensial dalam kemasan tersebut.

Dasar lain untuk memperjuangkan kesejahteraan seniman dan peningkatan kualitas seni pertunjukan wisata adalah tertuang dalam TAP MPR No.II/MPR/1993, khususnya dalam melaksanakan kebijaksanaan pembangunan 
lima tahun, yang menyebutkan :

"Pembangunan Kepariwisataan diarahkan menjadi sektor andalan yang mampu menggalakkan kegiatan ekonomi, termasuk kegiatan lain terkait, sehingga lapangan kerja, pendapatan masyarakat, pendapatan daerah, dan pendapatan negara melalui penerimaan devisa akan meningkat melalui upaya pengembangan dan pendayagunaan potensi kepariwisataan nasional".

Di samping itu untuk memahami seni pertunjukan dalam konteks kultural serta komersialnya, diperlukan konsep sosiologi yang berkaitan antara kelompok masyarakat dengan seni seperti dikemukakan Tommars (1964). Teori Tommars yang mengatakan bahwa satu bentuk masyarakat tertentu pasti akan menghadrikan gaya seni tertentu, dapat diterapkan pada perkembangan seni pertunjukan di Indonesia.

Dari berbagai studi pustaka yang akan dijadikan bahan analisis data, tampak jelas bahwa persoalan tentang seni pertunjukan lebih banyak diamati pada bagian cara membuat kemasan atau bentuk sajiannya. Kalaupun Sedyawati telah menekankan pada pentingnya faktor seniman dalam menentukan perkembangan seni pertunjukan, itupun belum meninjau figur seniman secara lengkap. Oleh karena mendudukkan posisi seniman dalam pengertian masyarakat sudah terkait pada fungsi hubungan dengan pribadi ataupun sebuah institusi lain. Oleh karena itu posisi seniman dalam bisnis pariwisata sebenarnya belum jelas. Hal inilah yang akan diamati dalam penelitian dengan judul Tantangan Seniman Seni Wisata Dalam Menghadapi Era Industri Pariwisata.

\section{Hasil Penelitian dan Pembahasan}

\section{Hasil Penelitian}

Desa Sembungan , Bangunjiwo, Kasihan Bantul adalah sebuah desa yang terletak di barat laut sentra kerajinan Kasongan Bantul. Desa ini memiliki potens kerajinan keramik dan seni tradisional. Salah satu diantaranya adalah seni langen Mandrawanara. Menurut pengakuan Ki Jiwaraya pimpinan grup Langen Mandra Wanara Sembungan, sejarah keberadaan Langen Mandrawanara di desanya telah lama dirintis, semenjak tahun 1970-an. Ketika itu ada dua orang warga desa Sembungan yang menyaksikan pertunjukan Langen Mandra Wanara di Kepatihan Danurejan Yogyakarta. Di sana mereka tidak terlibat langsung dalam pementasan. Namun bekal seni yang ada pada dua tokoh tersebut mampu memberikan inspirasi untuk mengembangkan seni Mandrawanaran ke desa aslalnya. Selang dua tahun kemudian, tepatnya tahun 1972, di desa Sembungan lahirlah sebuah grup seni Mandra wanaran. Dari segi garap dan penyajian tidak terlalu jauh berbeda.

Dari hasil penelitian di lapangan selama empat bulan, dari observasi, penjaringan pendapat, dokumentasi, dan wawancara dengan responden, data-data tersebut segara diolah untuk disusun sebagai satu laporan sebelum diseminarkan.
Kesimpulan dari seluruh responden dalam penelitian, melibatkan nara sumber yang berkompeten di bidang seni wisata yaitu :

1. Praktisi /pelaku seni wisata

2. Pejabat Pariwisata

3. Pengelola pertunjukan wisata

4. Pimpinan grup Langen Mandrawanara Sembungan

5. Wisatawan Mancanegara

menunjukkan bahwa, perlu adanya upaya untuk membuat kemasan baru paket wisata. Hal ini penting dilakukan karena selama ini di Yogyakarta kecenderungan penats untuk wisatawan didominasi Ramayana baik sendratari mupun wayang orang. Dengan demikian perlu pemikiran membuat paket dengan format berbeda meskipun episode yang diambil adalah Ramayana. Langen Mandrawanara dalam hal ini dapat dijadikan salah satu alternative pengembangan bentuk pertunjukan untuk wisata.

Berikut ini kami sampaiakan hasil penelitian kami sampaikan bahwa dasar untuk menampilkan seni Langen Mandra Wanara sebagai alternatif bentuk kemasan wisata adalah karena hampir seluruh tempat pertunjukan wisata saat ini didominasi pentas Ramayana. Oleh karena itu akan peneliti sampaikan perjalanan sejarah pertunjukan wisata di Yogyakarta.

\section{a. Sejarah Pentas Pertunjukan Wisata di Yogyakarta}

Menurut sejarah berlangsungnya pertunjukan pariwisata di Daerah Istimewa Yogyakarta, pertunjukan di Panggung terbuka Prambanan merupakan embrionya. Hal ini dikarenakan pertunjukan di kompleks candi Prambanan sudah digelar sejak tahun 1961. Namun demikian saat itu sebenarnya belum merupakan sajian khusus untuk wisatawan.

Perkembangan selanjutnya adalah upaya pengemasan kembali hasil pementasan untuk konsumsi wisatawan, yang akhirnya berkembang ke beberapa tempat di luar kompleks candi Prambanan. Munculnya beberapa tempat pertunjukan di luar Prambanan ini tentunya banyak menyedot seniman pendukung. Aktifitas inilah yang banyak menyita kegiatan para seniman baik tari maupun karawitan untuk menyajikan sebuah pertunjukan untuk konsumsi wisatawan.

Dampak dari penampilan secara rutin inipun dapat dinilai positif, tetapi juga tidak sedikit yang mengatakan negatif. Dari sisi seniman pelaku yang berasal dari pendidikan non formal (seniman alam) kegiatan ini adalah lahan yang sangat positif, karena mampu memberi tambahan penmdapatan (income) untuk keluarga. Namun bagi seniman formal baik mahasiswa maupun dosen yang terlibat hal itu belum tentu menjamin kebutuhan hidup sehari-hari. Dari dua alasan tersebut muncullah pro dan kontra mengenai upah minimal dari jasa pertunjukan wisata. 


\section{b. Pementasan di Hotel}

Tempat pementasan kedua adalah di hotel. Pentas di hotel juga masih didominasi Ramayana sebagai andalan pertunjukan. Tercatat dari Hotel Ambaraukmo (ketika masih aktif), Sahid, Hyatt, Santika, Garuda, semuanya menampilkan episode Ramayana. Meskipun durasi penyajian dipersingkat, namun tetap saja Ramayana dengan penyajian sama dengan di Prambanan atau Purawisata tidak memberikan warna lain pertunjukan wisata di Yogyakarta.

\section{c. Pentas Wisata non-Hotel}

Dari tempat pementasan non hotel nampaknya juga tidak bias lepas dari euphoria kejayaan Ramayana sebagai paket andalan. Dalem Pujokusuman, Dalem Joyokusuman, Dalem Kaneman, Dalem Yudaningratan semua menampilkan Ramayana sebagai asset untuk sajian wisata.

Dari pihak pebngelola pun mempunyai keyakinan bahwa Ramayana lah yang paling disukai wisatawan. Meskipuyn kenyataan tidak begitu. Oleh karena itulah variasi pertunjukan itu perlu dimunculkan agar kesan Ramayana centris dapat diminimalisir dengan menyajikan Ramayana dalam format berbeda.

\section{Pembahasan}

Dalam menghadapi tantangan perkembangan dan situasi saat ini Langkah-langkah yang harus ditempuh adalah:

1. Penegakan idealisme untuk memajukan Daerah Tujuan Wisata

2. Menjaga prestise Kesenian di mata wisatawan mancanegara

3. Memberikan service bagi wisatawan tanpa harus mengorbankan faktor

estetis Tiga hal itu merupakan inti permasalahan yang akan dihadapi

seniman dalam partisipasinya di dunia wisata.

Pertama terkait dengan idealisme. Hal ini perlu dikedepankan karena seniman merupakan asset berharga untuk mendukung suksesnya program pariwisata khususnya sektor seni pertunjukan. Tidak dapat dipungkiri lagi bahwa potensi sumber daya seniman di sini menjadi satu harapan masa depan dari wajah pariwisata secara umum di Indonesia dan di Yogyakarta khususnya.

Untuk mewujudkan langkah ini dibutuhkan sikap profesional secara utuh Pengertian profesional inilah yang harus diartikan secara benar. Sementara in profesionalisme masih diartikan sepotong, yaitu "bayaran". Padahal art profesionalisme secara utuh tidak hanya faktor "bayaran" melainkan meliput sikap dan tindakan seseorang (seniman) dalam memperjuangkan keberadaan kesenian (Bagong K, 1999).

Sikap inilah yang belum dapat diwujudkan di era global oleh insan sen pertunjukan khususnya yang terlibat dalam dunia seni wisata. Langkah apa yang harus kita tempuh untuk solusi permasalahan tersebut, sebenarnya kembali kepada masing-masing individu dalam mengartikan dan memaknai pengertian profesional secara utuh. Tanggung jawab moral merupakan landasan utama untuk mewujudkan cita-cita tersebut.

Hal yang kedua menjada prestise seni pertunjukan yang ditampilkan merupakan konsekuensi langsung dari sikap profesional yang ditunjukkan seniman. Artinya kalau seniman peduli dengan sikap profesional tersebut maka secara tidak langsung akan ikut serta dalam menjaga citra atau gengsi seni pertunjukan itu sendiri di mata orang asing.

Langkah ketiga dengan memberi service atau layanan untuk wisatawan dalam pengertian menyajikan sesuatu harus secara baik dan benar, meski dihidangkan untuk orang yang tidak tahu tentang kesenian itu. Hal ini penting disadari, karena kebayakan pelaku seni menganggap wisatawan mancanegara tidak tahu. Maka mereka sering tampil seenaknya. Ini sesuatu kekeliruan yang akan berakibat fatal bagi nama baik seniman itu sendiri maupun kesenian dan daerah di mana kesenian itu berada. Anggapan seperti harus dikikis habis, kalau kita kita ingin menuntut peningkatan kesejahteraan dari imbalan jasa menari untuk wisatawan. Ini terkait dengan penilaian seseorang dalam membawakan sebuah tarian tertentu. Kalau kualitas seseorang dapat diandalkan, maka harga jualnya pun akan tinggi, dan sebaliknya.

\section{a. Solusi Terhadap Permasalahan}

Ada beberapa penyelesaian yang dapat ditempuh untuk mengatasi permasalahan tersebut. Secara internal maupun eksternal. Internal terkait dengan tanggung jawab individu, dalam menghadapi persaingan global. Kedua masalah eksternal antar organisasi pengelola pertunjukan seni wisata, harus dapat menjalin koordinasi yang kondusif. Kedua penyelesaian tersebut untuk langkah antisipasi demi peningkatan lama timnggal wisatawan (length of stay) di Yogyakarta yang selama ini masih di bawah 2 hari.

Seperti dikemukakan Sunardi, pelaku seni wisata bahwa sudah saatnya seni wisata dikembangkan tidak hanya sendratari Ramayani tetapi format baru seperti Langenmandrawanara. Menurut sunardi, Mandrawanara memiliki ciri khusus yang ada kemiripan dengan Opera di barat. Karakteristik inilah yang dapat dijadikan alternatif penyajian Langen Mandrawanara sebagai aset pariwisata di Yogyakarta (Wawancara, tanggal 12 September 2006)

Dalam pandangan Ki Jiwaraya selaku pimpinan grup Langen Mandrawan di desa Sembungan, bentuk penyajian Langen mandrawanara tidak terlalu sulit dikemas ulang untuk wisatawan. Menurutnya, aspek durasi menjadi sasaran utama agar tidak terlalu lama. Secara rinci Ki Jiwaraya memberikan deskripsi penyajian Langen Mandarwanara sebagai berikut :

\section{b. Bentuk penyajian Langen Mandra Wanara}

Secara prinsip bentuk penyajian Langen Mandra Wanara tidak jauh berbeda dengan pertunjukan Ramayana. Episode (cerita), kostum, dan alur cerita sama. Hanya perbedaan prinsip pada teknik penyajian yang dilakukan dengan 
berjongkok dan dialognya dengan tembang (vocal) Dua esensi ini yang akan membedaskan Mandra Wanaran dengan pentas Ramayana.

Struktur pengadegan dalam Langen Mandrawanara dapat dibuat secara variatif. Ada beberapa pilihan yang dapat dibuat untuk setiap episode.

1) Episode Ramayana

Ada beberapa episode yang dapat disajikan dalam Langen Mandrawana yakni dari Sinta Hilang sampai Sinta Obong. Dalam pembagian episode dapa dibuat sanggit atau penggarapan menurut selera. Diantara episode tersebut terdapat lakon-lakon Subali Lena, Anoman Duta, Anggada Balik, Sayempraba Maeka, Kumbokarno Gugur, hingga Sinto Obong. Episode-episode tersebut dapat dibuat masing-masing dengan durasi relative tidak terlalu panjang untuk ukuran wisatawan , misalnya 1 jam atau maksimal 1,5 jam.

2) Jejeran

Jejeran (adegan Kerajaan) dapat divariasi dari dua kerajaan utama yang bersengketa yaitu Alengkadiraja dengan Ayodya. Dapat pula disisipi dengan kerajaan ketiga yang ikut serta dalam konflik kepentingan serta memihak salah satui kerajaan. Namun pada intinya adalah konflik dua Negara menjadi sentral atau focus penyajin.

3) Penokohan

Penokohan yang dimunculkan adalah seputar perlawanan Prabu Ramawijaya yang hendak merebut kembali Sinta dari tangan Rahwana Ramawijaya dibantu laskar Kera dibawah komando Patih Sugriwa dan senopat Anoman. Alengkadiraja diperintah Rahwana sang raja angkaramurka. Dengan dibantu patih Prahasta hingga senopati agung Kumbokarno.

4) Sumber konflik

Sumber konflik utama dalam episode Ramayana adalah keberadaan Sinta di Alengkadiraja. Diawali dari hilangnya Sinta ketika berada di hutan Dandaka. Atas pertolongan Jatayu, jejak dan keberadaan Sinta diketahui Rama. Dari situlah Rama dan laskarnya mencoba untuk merebut kembali. Akhir dari episode ini adalah diketemukannya Sinta yang diakhiri dengan ritual pembakaran sebagai pembuktian kesucian Sinta.

5) Dialog

Dialog atau komunikasi antar tokoh dalam Langen mandrawanara in menggunakan tembang. Bentuk tembang dalam langen Mandarwanara ini disebu dengan Rambangan. Ada beberapa karakteristik tembang yang digunakan dalam dialog ini misalnya :

(1) Untuk adegan kerajaan menggunakan tembang Dhandhanggula, Mijil

(2) Untuk adegan peperangan menggunakan tembang Durma, Pangkur

(3) Untuk adegan sedih Maskumambang
Dalam mengungkapkan maksud cerita melalui tembang dilakukan sekali (satu pupuh tembang) itupun tidak digunakan hanya satu tokoh, namun dapat satu pupuh digunakan dua hingga tiga tokoh. Dengan cara ini waktu akan dapat dipersingkat tetapi tujuan tercapai.

Kedua masalah variasi tembang. Dalam ketentuan Mandrawanaran jenis tembang macapat hampir semuanya digunakan. Hanya saja dalam kepentingan tertentu yang serba pendek, tiga jenis tembang seperti tercantum di atas sudah mewakili tiga suasana sudah cukup.

6) Iringan

Pengiring Langen Mandrawara menggunakan gamelan Slendro dan Pelog. Namun kebiasaan di desa Slendro lebih dominan digunakan dengan alasan keterbatasan alat. Namun demikian kini Pelog pun mulai digunakan, karena akan menambah variasi jenis tembang yang digunakan. Struktur pengunaan gamel;an sama sepertti dalam wayang wong mataraman, yaitu kalau slendro menggunakan laras pathet 6,9 , dan diakhiri manyuro. Jika menggunakan pelog diawali dengan pelog 6, 9 dan pathet barang.

7) Kostum

Busana yang digunakan dalam Langen Mandrawanara masih sama dengan penyajian Ramayana, hanya perbedaannya pada rias. Pada pertunjukan Ramayana bentuk klasik wayang wong menggunakan topeng penutup muka untuk tokoh kera, raksasa. Untuk Langen Mandrawanara topeng tidak utuh (separo). Hal ini dimaksudkan untuk supaya tidak menghambat suara ketika penari melantunkan tembang. Bahkan ada kemungkinan tidak menggunakan topeng sama sekali, namun dirias sesuai dengan karakter kera dan raksasa yang diperankan.

8) Sanggit cerita

Cerita utuh dalam episode Ramayana dapat dilakukan dengan sebelas episode. Namun dalam prakteknya, episode tersebut sering diringkas menjadi empat atau lima episode. Bahkan untuk Ramayana di Prambanan ada episoe full story. Ini artinya pemadatan dapat dilakukan dengan teknik sanggit yang tepat.

Dalam konsep seni wisata, pemadatan sepeti ini memiliki persyaratan khusus yakni :

(1) Tidak kehilangan substansi cerita

(2) Penyajian tetap terlihat utuh, meskipun durasi pendek (tidak tergesa-gesa)

(3) Dramatik tetap harus dipertahankan

Persyaratan tersebut di atas dapat ditempuh untuk mengungkap sebuah episode tertentu supaya wisatawan tidak kehilangan imajinasi cerita yang telah mereka kenal terlebih dulu. Salah satu contoh lakon Triyangga Takon Bapa (Video pertunjukan terlampir) bentuk asli penyajian berlangsung 2 jam. Namun untuk keperluan wisatawan dirinmgkas menjadi 1 jam tanpa istirahat. Untuk kemasan Langen Mandrawanran durasi 1 jam ini sudah sangat pendek, sehingga tidak bias 
dipaksakan lebih pendek lagi, kecuali pethilan beksan yang hanya bnerdurasi 10 menitan.

Strategi pemadatan dengan satu lakon 1 jam dengan menyertakan lagon dan kandha bersamaan. Baru kemudian dilanjutkan dengan buka gendhing jejer pathet Nem. Jogetan dilakukan hanya sekali terus tayungan (jalan) Sembahannya pun dilakukan bersama antara Raja dan rakyat, tidak seperti dalam wayang wong yang dilakukan bergantian. Tambang yang dilantunkanpun berselang seling. Satu contoh dialgog antara Batara Narada dengan Dewi Urangayu dalam episode Triyangga takon Bapa.

Bentuk utuh satu pupuh Dhandhanggula dibawakan satu tokoh. Namun untuk efisiensi waktu satu pupuh dapat diguankan dua tokoh. Contoh sebagai berikut :

\section{Bathara Narada :}

\section{Dhandhanggula Slendro sanga:}

Wis ta Nini haywa tawang tangis,

sejatine trimala wus ruwat,

awit karsaning ywang manon

\section{Dewi Urangayu :}

Kados pundit pukulun,

Kula prawan teka who siwi

Wus nora dadi apa,

Iki lair kakung,

Jenenge bambang Triyangga,

Arsa ingsun gege si jabang bayi,

Haywa kita sumelang.

\section{(Wawancara dengan Ki Jiwaraya, di desa Sembungan 4 September} 2006)

\section{c. Pendapat Tokoh}

Drs. M. Sudibyo, Kasi Seni Budaya Dinas Pariwisata Seni dan Budaya Yogyakarta memberikan gambaran bahwasannya bentuk kemasan seni wisata akan memberikan daya tarik bagi wisatawan yang berkunjung ke Yogyakarta secara umum. Oleh sebab itu kemasan apapun perlu digarap secara professional (wawancara, 26 Agustus 2006)

Dalam pandangan RM. Soedarsono, seperti ditulis pada hasil penelitian tentang Seni Pertunjukan dan Pariwisata Indonesia (2000 : 117) dikemukakan bahwa pentingnya membuat bentuk kemasan yang semakin variatif. Hal ini akan memungkinkan wisatawan tinggal lebih lama di daerah tujuan wisata. Oleh sebab itu Soedarsono memberikan rekomendasi bahwa bentuk dan jenis pertunjukan di Yogyakarta hendaknya dibuat lebih variatif tidak hanya Ramayana Ballet seperti yang disajikan di Prambanan maupun Purawisata.
Jozef Mlynarczik, wisatawan mancanegara dari Hongaria yang ditemui di bangsal Sri Manganti Kraton Yogyakarta, lebih senang melihat pertunjukan di tempat asal. Artinya mereka tidak suka pertunjukan yang sudah di kermas di hotelhotel. Oleh sebab itu Jozef, sengaja memilih tempat di mana kesenian itu berasal. (wawancara dengan Jozef, hari Minggu, tanggal 17 September 2006, di bangsal Sri Manganti Kraton Yogyakarta)

Pandangan yang sama diungkapkan Terry Clark, seorang wisatawan dari Amerika Serikat yang mengungkapkan kesenangannya melihat pertunjukan tradisional di desa asal kesenian itu. Mereka merasa mendapatkan sesuatu yang lain dan itu merupakan kenangan yang tak terhingga, ketika mereka kembali ke negeri asalnya. (wawancara dengan Terry Clark di bangsal Sri Manganti, 17 September 2006)

Pendapat-pendapat tersebut menguatklan bahwa upaya pengemasan pertunjukan Langen Mandrawanara di desa Sembungan akan memiliki nilai jual tinggi. Di samping itu motivasi wisatawan mancanegera pun akan meningkat untuk menyaksikan pertunjukan tersebut. Oleh sebab itu upaya Ki Jiwaraya untuk merlatih potensi warga Sembungan dengan Langen Mandrawanara adalah langkah posisif untuk menyongsong dibukanya kawasan Sembungan sebagai daerah tujuan wisata.

Dari sisi ekonomis, pengemasan bentuk pertunjukan Wisata Langen Mandrawanara akan memberi keuntungan secara materiil. Hal ini dimungkinkan karena dengan kunjungan wisatawan ke lokasi pertunjukan Mandrawanaran akan menghidupkan roda perekonomian desa setempat. Hal ini sesuai dengan pandangan Ir. Yuwono Sri Suwito, seorang pakar pariwisata yang mengatakan bahwasannya pertumbuhan ekonomi di sektor pariwisata akan sangat ditentukan oleh strategi pengemasan wisata (Makalah disampaikan dalam Seminar Pengembangan Pariwisata, 2005, Dewan Kebudayaan Propinsi DIY)

Ki Jiwaraya sebagai pengelola grup Langen Mandrawanara memberikan tanggapan positif terhadap upaya pengemasan bentuk Mandrawanaran sebagai asset wisata. Menurutnya Mandrawanaran memiliki daya tarik dan keunikan dalam penyajian. Ia mencotohkan bagaimana dialog tembang tokoh disampaiakn dalam pertunjukan. Demikian pula untuk penampilan dengan berjongkok akan memberikan daya tarik lain, karena Ramayana pada umumnya yang pernah wisatawan tonton dilakukan dengan bentuk sendratari (ballet) (Wawancara dengan Ki Jiwaraya, 4 September 2006 di desa Sembungan.

\section{Penutup}

Dari hasil penelitian yang kami ungkapkan di atas terbukti bahwa, kemasan wisata akan berpengaruh pada upaya peningkatan lama tinggal wisatawan di suatu daerah. Yogyakarta sebagai Daerah Tujuan Wisata perlu 
memikirkan langkah ke depan agar sajian wisata lebih variatif. Menginga pertunjukan wisata yang terjadi saat ini masih diomominasi bentuk Ramayana Ballet.

Upaya mengangkat seni Langen Mandrawanara (Opera Jawa) dengan cerita Ramayana merupakan langkah konkret yang pantas didukung. Dari sisi budaya akan ikut mendukung upaya pelestarian. Dari sisi ekonomi, keberadaan tempa pertunjukan wisata di sesbuah desa, akan menghidupkan roda perekonomian masyarakat setempat, di samping mampu memberikan peningkatan kesejahteraan bagi warga yang memiliki usaha di sekitar lokasi pementasan.

Langkah ke depan semoga pihak pemerintah daerah dalam hal ini Dinas pariwisata Kabupaten Bantul, khususnya dan pemerintah Propinsi DIY mendukung upaya meningkatkan lama tinggal wisatawan dapat terwujud. Dan yang tak kalah penting adalah kesadaran pelaku wisata dalam ikut memajukan potensi wisata yang ada di Yogyakarta. Dengan langkah itu berarti pula ikut serta melestarikan sambil mempromosikan kawasan wisata di daerah

\section{Daftar Pustaka}

Bahan Penataran P-4. TAP MPR No. II/MPR/1993. Jakarta : Dirjendikti, Depdikbud.

Grabburn, Nelson HH, 1976. Etnic and Tourist Arts, New York City.

Hopkins, Jerry, 1981. The Hula, Hawaii University Press

Kayam, Umar (1981). Seni, Tradisi, Masyarakat. Jakarta : Sinar Harap

Kuswarsantyo. (1996). Perkembangan Tari Jawa di Yogyakarta dalam

Menghadapi Tantangan Industri Pariwisata. Tesis : Universitas Gadjah Mada Yogyakarta.

Maquet, J. (1971). Introduction to Aesthetic Anthropology. Massachusetts: Addison Wesley.

Sedyawati, Edi (1981). Pertumbuhan Seni Pertunjukan. Jakarta : Sinar Harapan. Senen, I Wayan, 1996, Seni Wisata, Komponen utama dalam Mensukseskan Industri

Pariwisata, FSP ISI Yogyakarta (Penelitian HIBAH Perguruan Tinggi) Soedarsono,

RM. (1990). Seni Pertunjukan Jawa Tradisional dan Pariwisata di Daerah

Istimewa Yogyakarta. Yogyakarta : Depdikbud, Dirjenbud.

, (1995). Validitas Seni Tari Jawa: Sebuah Dampak Perkembangan Seni Pertunjukan Wisata di Daerah Istimewa Yogyakarta. Yogyakarta: Gama Press.

Spillane, James. (1991). Ekonomi Pariwisata. Yogyakarta : CV Kanisius.

Tommars, Adolph S. (1964). Class System and the Arts, in Werner J. Cahnman, and Avin Boskoff, eds. Sociology and History Theory Reasearch London : The Free Press of Glence. 